There is now only one experiment left. This relates to the effect of curvature in the streams on the stability of the motion. Here again we see the whole effect altered by apparently a very slight cause. If the water be flowing in a bent channel in steady streams, the question as to whether the motion will be stable or not turns on the variation of the velocity across the channel. In front of the lantern is a cylinder with glass ends, so that the light passes through in the direction of the axis. 'The cylinder is full of water, the disk of light on the screen being the light which passes through this water, and is bounded by the circular walls of the cylinder. By means of two tubes temporarily attached, a stream of colour is introduced so as to form a colour-band right across the cylinder, extending from wall to wall ; the motion is very slow, and, the taps being closed and the tubes removed, the colour-band is practically stationary. The vessel is now caused to revolve about its axis. At first only the walls of the cylinder move, but the colour-band shows that the water gradually takes up the motion, the streak being wound off at the ends into two spiral lines, but otherwise remaining still and vertical; when the streak is all wound off and the spirals meet in the middle, the whole water is in motion. But as the vessel is revolving, the motion is greatest at the outside, and is thus stable. There are no eddies, although the spiral rings are so close as nearly to touch each other. The vessel stops, and gradually stops the water, beginning at the outside. If this went on steadily, the spirals would be unwound and the streak restored; but as the velocity is now greater towards the centre, the motion is unstable for some distance from the outside, and eddies form, breaking up the spirals for a certain distance towards the middle, but leaving the middle revolving steadily. Besides indicating the effect of curvature, this experiment neatly illustrates the action of the earth's surface on the air moving over it, the variation of temperature having much the same effect on the stability of the moving fuid as the curvature of the vessel. The moving air is unstable for a few thousand feet above the earth's surface, and the motion consequently sinuous to this height. The mixing of the lower and upper strata produces the heavy cumulus clouds, but above this the influence of the temperature predominates; the motion is stable, and clouds, if they form, are stratus, like the inner spirals of the colour-bands.

\section{REPORT ON ATMOSPHERIC SAND.DUST} FROM UNALASKA ${ }^{1}$

THE specimen of sand which fell during a rain-storm, October 20, 1883, at Unalaska. Alaska, has been submitted to microscopical analysis, and found to be undoubtedly of volcanic origin. It is gray, and the grains are rather uniform in size, rarely attaining a diameter of $0.35 \mathrm{~mm}$. Under a hand lens can be distinguished light-coloured crystals and fragments which are occasionally glassy in lustre, mixed with others of darker colours; both are more or less dusty in appearance from the presence of finer particles. For convenience of manipulation and preservation, as well as to render the optical tests more definite and decisive, the sand was mounted in Canada balsam upon glass slides, after the manner of thin sections of rocks for microscopical investigations. It is composed chiefly of either broken or complete crystals of feldspar, augite, hornblencle, and magnetite, with numerous fragments of ground-mass and a few small particles of glass freighted with grains of iron oxide or other heavy minerals. The feldspar frequently occurs in wellpreserved crystals. Cleavage plates are common, but irregular fragments predominate. A few thin cleavage lamella parallel to the base between crossed nicols show no bending due to polysynthetical twinning, and extinction takes place when the lines which indicate the clinopinacoidal cleavage are parallel to the principal section of either nicol. While it is evident that stuch thin plates are orthodase, the prevailing feldspar is undoubtedly basic plagioclase, for chemical analysis shows the sand to contain only 52.48 per cent. $\mathrm{SiO}_{2}$. The perfect crystals are usually about $0^{\circ} .15 \times 0.13 \mathrm{~mm}$. in size, and slightly tabular, parallel to the clinopinacoid. At times they present an almost hexagonal aspect, and gencrally contain inclusions so abundantly as to render the middle portion feebly translucent. Among the imprisoned particles may be recognised horbblende microlites, grains of iron oxide with crystallites of an indeterminable nature, and their arrangement frequently imparts a distinct zonal structure to the feldspar. The hornblende, which is not nearly as

${ }^{x}$ By J. S. Diller, Assistant Geologist, United States Geological Survey. prominent a constituent of the sand as the feldspar, occurs chiefiy in cleavage plates and irregular angular fragments. It has a brown to dark brown colour, with deep absorption and strong pleochroism, as in the andesite which it characterises. The size of the hornblende fragments varies within small limits, averaging $0.10 \times 0.05 \mathrm{~mm}$., and the extinction angle is about $9^{\circ}$. It occasionally contains numerous crystallites arranged parallel to the vertical $\left(c^{\prime \prime}\right)$ axis. In the number of slides examined several brownish folix, apparently of biotite, were observed under such circumstances that their characterising optical properties could not be satisfactorily determined. Of the $\mathrm{FeMg}$ silicates augite is the most abundant. It is of a pale green colour, non-pleochroitic, and its angle of extinction as seen in the cleavage plates is about $46^{\circ}$. Like hornblende, it is found generally in irregular fragments. The prismatic fragments vary from $0^{\circ}$ Io to $0^{\circ} 35 \mathrm{~mm}$. in greatest length. The grains of magnetite, which may, in considerable quantities, be readily picked out of the sand with a magnet, are for the most part of irregular outline and small size. Instead of forming independent grains of themselves, they are generally found cleaving to fragments of the ground-mass, or included in the other minerals.

Besides the mineral ingredients already mentioned, the sand contains numerous irregular grains swarming with clear crystallites and microlites embedded in a grayish translucent to transparent, often amorphous, base. These composite fragments correspond to the ground-mass of the eruptive rocks to which the volcanic sand is allied. They vary in size up to a diameter of $0.26 \mathrm{~mm}$., and are generally rendered heavier than they would otherwise be by small particles of magnetite or augite. The crystal fragments frequently have portions of the ground-mass attached to them, and present that ragged appearance which distinguishes volcanic sand from that which has been produced by other methods. Feldspar, augite, hornblende, magnetite, with fragments of the ground-mass, make up the bulk of the sand. Its composition is that of a hornblende-andesite very like those which occur at many points along the western coast. One is surprised to find a conspicuous deficiency in the most common and generally prevailing element of volcanic ashes. It is true that clear or sparingly microlitic glass particles are found in the sand from Unalaska, but they are rather exceptional and uncommon. This paucity in glass fragments may be readily comprehended by reflecting upon the origin and distribution of volcanic ashes.

The United States Geological Survey party sent out last summer in my charge under the direction of Capt. Dutton for the reconnaissance of the southern portions of the Cascade Range, collected a lot of volcanic sand about a dozen miles north-cast of Mount Shasta. It does not form a thick deposit, but is widespread over the basaltic slopes south of Sheep Rock, and like that collected at Unalaska consists chiefly of crystal fragments, of which feldspar is the most abundant. Hornblende, hypersthene, augite, and magnetite are less prominent. In addition to these and numerous fragments of microlitic ground-mass, there are many clear or sparingly crystallitic glass particles of a pumiceous character. The composition of the sand is that of a hypersthene-bearing hornblende-andesite like that which forms the well-preserved and prominent crater springing up from the north-western slope of Mount Shasta, about two miles from that summit. This crater is the counterpart of Shasta cone, when we consider the whole volcanic pilc, and las been christened Shastina by Capt. Dutton to indicate the relation it bears to its majestic neighbour. In the volcanic sand which traveller about a dozen miles north-east from Shastina, grains may be found having a diameter of $0.5 \mathrm{~mm}$., so that it is, on the whole, considerably coarser and less uniform than that which fell at Unalaska, October 20, 1883, but like the latter it is made up chiefly of fragments of crystalline matter.

On the other hand, volcanic dust which has been carried long distances is composed principally of glass particles, and there is a conspicuous paucity of crystals and fragments of dense microlitic ground-mass. That which emanated from a crater in Iceland and fell over Norway and Sweden March 29 and 30, 1875 , more than 750 miles from its sonrce, is composed almost exclusively of sharp-edged angular glass fragments with curved sides. These splinters, chips, and shards of glass show by their more or less curved outlines, as well as by their tubular or vesicular structure, that they differ from pumice only in being fragmental. In the formation of pumice the inflation and distension by in closed steam and gases is carried so far as to produce a froth, but if the same process be continued until cxplosion takes place, 
volcanic dust will be the result. The same might be said of the Krakatoa dust which has been collected far from its source. That which fell August 27 at Batavia, about sixty miles from Krakaton, according to Renard, consists chiefly of glass particles, with plagioclase, augite, rhombic pyroxenc, and magnetite, giving the general composition found in some augite-andesites In Krakatoa dust and pumice obtained from various localities in the vicinity of the Java coast, I have always found glass the most abundant constituent. The rhombic pyroxene, hypersthene, predominates largely over augite, and as Mr. Iddings has already shown, the ejected material belongs to hypersthene-andesite very like the pumiceous variety of the same rock upon the southwestern slope of Mount Shasta in the Cascade Range.

While it is evident that all kinds of ejected material, from the finest dust to the coarsest fragments, may be found upon their parent cone, yet it is true that all ashes which have been transported by the winds for distances greater than one hundred miles are composed chiefly of glass fragments distinguished by their pumiceous character. Volcanic glass may be considered an almost inevitable product of violent eruptions ; and of all the important constituents of sand and dust formed in this way, it is the lightest. Furthermore, for a reason easily explained, it is blown to much finer dust-particles than any of the products of crystallisation. In a magma where crystallisation is taking place, the absorbed gases and uncombined water under enormous tension are gradually accumulated in that portion which is most liquid and least individualised. In this way the portion of the magma which upon solidification yields glass becomes stored with the energy that will cause its distension and perhaps blow it to atoms when the mass is relieved from the antagonising pressure. The individualised and unindividualised portions of the magma may be irregularly commingled, or they may arrange themselves, as is frequently the case in obsidians from Oregon, in more or less regular alternating bands. The streams of microlites must necessarily imprison less uncombined water or absorbed gases than the bands between them, so that when the pressure is relieved the latter will suffer the greatest amount of distension. If the tension of the confined water and gases is great enough, the amorphous portion of the magma may be blown to glassy dust, while the individualised portion, pulverised rather by external than internal forces, is not reduced to so high a degree of fineness. Volcanic dust is the extreme term of a series which begins in compact lava, and has for its middle members pumice in different stages of inflation. It appears to be a significant fact, at least as far as I have had an opportunity to observe, that effused pumice, i.e. pumice which occurs in places as froth upon a stream of obsidian into which it gradually passes, is highly microlitic. The glassy partitions which bound the more or less rounded vesicles are crowded with microlites and crystallites, while in ejected pumice where long, distended vesicles prevail, or in volcanic glass dust, the products of crystallisation are comparatively few or entirely wanting.

Prof. F. W. Clarke, chief chemist of the United States Geological Survey, has determined the amount of silica in the sand which fell at Unalaska, as well as that from the north-eastern slope of Mount Shasta. The former contains $52.48 \mathrm{SiO}_{2}$. As should be expected, it is more basic than hornblende-andesite, and indicates that the acid portion of the magma-the volcanic glass in the form of dust-was blown away from the sand. It is well known that the glassy base is in general the most acid portion of a rock, and any mechanical means by which the magma is separated into crystal sand and glass dust divides the rock into a basic and acidic portion. This division is in certain degrees indicated by the analysis of Renard and Iddings of material from the recent eruption of Krakatoa. The pumice contained only 62 per cent. of $\mathrm{SiO}_{2}$, while the dust which fell at Batavia, according to Renard, contained 65 per cent. of $\mathrm{SiO}_{2}$. 'The few observations I have been able to gather indicate that even under favourable circumstances volcanic sand is not carried a hundred miles from its source, while dust from the same vent may be distributed over many hundreds of miles beyond the sand.

It is unfortunate that we do not possess more definite and detailed knowledge with reference to the source and distribution of the volcanic sand from Unalaska. Mr. Applegate, in his letter of transmittal dated October 22, says, "I forward by this mail a sample bottle of sand that fell during the storm of October 20, I883. At 2.30 p.m. the air became suddenly darkened like night, and soon after a shower of mixed sand and water fell for about ten minutes, covering the ground with a thin layer. The windows were so covered that it was impossible to see through them. This sand is supposed to have come either from the Makushin or the new volcano adjacent to Bogeslov. The former is a distance of about nineteen miles to the south-west, but for years has only issued forth smoke or steam. The latter is a new one which made its appearance this summer, and burst out from the bottom of Behring Sea. It has been exceedingly active, and has already formed an island from 800 to $\mathbf{I} 200$ feet high. Bogeslov is about sixty miles from here (Unalaska) in a west direction. The new volcano is about one-eighth of a mile north-west of it." Judging alone from the size of the grains of sand it secms probable that it may have been brought from Bogeslov. Its paucity in glass fragments as compared with the coarse sand from a dozen miles north-east of Shastina, indicates that it was carried a considerable distance from its source, so as to allow a pretty complete assorting of the material by the wind.

Grewingk, who has given us the most important contribution to the geology of Alaska, more especially of the Aleutian Islands, has prepared a geological map of Unalaska, and reports the volcanoes there as emitting basic lavas which, from his meagre description, appear to be similar to those poured out by volcanoes of the Cascade Range. It seems very probable that the volcanic sand ejected by Makushin must be of the same general composition as that which lately fell at Unalaska. Grewingk's work contains a description of the island of Bogeslov, but in it are contained no petrographic notes of importance. Of the rocks on the new volcanic island north-west of Bogeslov, for which the name Grewingk has been proposed, we have no information. If the sand under consideration really came from Grewingk, as seems most probable, we should expect the island to be marle up of hornblende-andesite.

In connection with the all-absorbing topic, the peculiar sunset phenemena, much has been said of volcanic dust from Krakatoa. A surprisingly wide distribution has been assigned to it, and there is doubtless considerable scepticism concerning its identification. The forms of glass particles in volcanic dust are peculiar, and this, taken in connection with their isotropic character, renders them easily recognised under a polarising microscope. In the annexed figures Series No. I gives the outlines of glass fragments in Krakatoa dust. Series No. 2 is taken

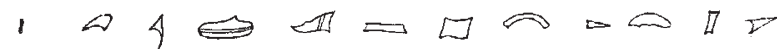
2 $\Delta \curvearrowright 4$ 再 $\triangle 2$
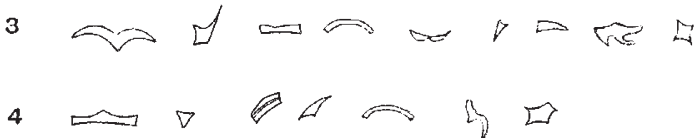

from the volcanic dust which fell in Norway and Sweden, March 29 and 30,1875 . Series No. 3 represents the curious fragments found in an old quartz-porphyry tufa at Breakheart Hill, in Sangus, north of Boston. The forms of glass particles seen in the volcanic dust collected by Mr. Russell near the Truckee River are represented in Series No. 4. The fragments represented in Series No. 3 are now chiefly quartz, but were once particles of volcanic glass, and show that in the early geological history of Eastern Massachusetts there were volcanoes belching forth volcanic ashes like that of recent times, and flooding the country with acid lavas whose beautiful and regular fluidal banding has puzzled many observers and led them to suspect its sedimentary origin. It seems reasonable to suppose that the Grewingk crater must have yielded dust as well as sand, and that the former can, with a high degree of probability, be distinguished from the dust of Krakatoa. The glass dust from Grewingk, judging from that seen in the Unalaska sand, is less clouded than that from Java. In the Krakatoa dust it is hypersthene which is associated with the feldspar, augite, and magnetite, but in Grewingk dust we should expect to find hornblende.

A complete knowledge of the distribution of volcanic sand and dust has such an important bearing upon meteorological conditions, as well as upon volcanic phenomena, that it is hoped accurate and continuous observations may be made upon this subject at suitable meteorological stations. When we consider the dust in cities rising from the ground into the air during dry weather, as well as contributions, frequently glassy, made by 
various furnaces and factories, it is evident that observations for meteoric and volcanic dust should be made at elevated stations far removed from large cities. If a station were established upon Mount Shasta, California, as suggested by Mr. Gilbert Thompson, it would afford excellent opportunity for such observations. The station on Mount Washington is also favourably situated, and if regular observations were made at these stations and in Alaska for small as well as large quantities of such dust, and the sediments collected subjected to microscopical examination, the result would doubtless be of great interest.

Washington, D.C., March 25

\section{THE POLAR CONFERENCE ${ }^{1}$}

THE Fellows need hardly be reminded that it was at the suggestion of an Austrian, the late Carl Weyprecht, that this great international undertaking was set on foot, and accordingly Vienna was the most fitting city in which to welcome the several expeditions on their return to civilisation, and to discuss the best mode of utilising their labours.

The chiefs of nine expeditions were present at the meeting. The uncepresented stations were the two Russian ones, at Nova Zemlya and at the mouth of the Lena (at which latter station the observations will be continued until August I884); that established by the Society of Science of Finland at Sodankylä, the German station in South Georgia, and the second Amcrican station at Lady Franklin Bay. As to the fate of the observers at the last-named locality there are unfortunately grave reasons for anxiety.

Most of the expeditions had brought home a collection of photographs, giving a vivid representation of their respective surroundings during their sojourn. Many of these possess ethnological interest, and one was humorous, as it showed the Dutch Arctic tin band, with instruments made out of preserved meat canisters.

I suppose my audience is aware that the Dutch Expedition was ice-bound and drifted about in the Kara Sea, ultimately saving itself in its boats. The ship was crushed in the autumn of 1882 , but did not actually sink for six months, so that all the property was saved. Under such circumstances, however, it is no wonder that no magnetical observations were made.

As regards the publications, these are to be carried out independently in each country, but on a uniform plan. The meteorological observations are to be given in metric and centigrade measures ; the magnetical according to the C.G.S. system of units.

The hourly observations are to be published in detail. The barometer observations are not to be corrected for gravity, but the value of this correction is to be given in the tables.

As regards terrestrial magnetism, besides the publication of the term day observations a detailed reproduction of all the observations for certain days of disturbance is to be given. A list of these days will be prepared by Prof. Wild.

All the members of the Conference are requested to collect data for earth currents for their respective countries during the period of the circumpolar observations. The auroral observations are to be published on the scheme proposed by Weyprecht.

As to the magnetic disturbances and their elimination there was, as might be expected, a long debate, but no definite resolutions were adopted.

The publication of a number of observations was left optional, such as evaporation, solar radiation, the resolution of the wind to four components, the calculation of wind-roses according as the pressure was above or below $760 \mathrm{~mm}$., \&c.

It is hoped that the whole of the results will have appeared by the end of 1885 .

The Conference was most graciously received by the Emperor at an audience. The members were also entertained at a magnificent banquet on April 23 by Count Wilczek, at whose sole expense the Austrian Expedition to Jan Mayen had been fitted out and maintained during its stay.

The detailed report of the proceedings of the Conference will be published in French and German, and will appear before long.

\section{GEOLOGY IN RUSSTA}

A LTHOUGH a large amount of geological work has been done in Russia, especially during the last twenty years, the geological exploration of this wide region has not been carried I Notes on the Proceedings of the International Polar Conference, held at Vienna, April 17-24, r884. Read at the Royal Meteorological Society by
Robert H. Scott, F.R.S., President. on in the detailed and accurate manner required by modern geology. An important step towards the attainment of more precise knowledge on this subject was taken in $\mathbf{1} 882$ by the formation of a special Geological Commission intrusted with the geological survey of Russia. A yearly subsidy of 30,000 roubles was granted for that purpose by the State, to which must be added various occasional subsidies for special aims, supplied either by Government or by provincial assemblies and private bodies. This Commission has now published two volumes of its Bulletin and one fasciculus of Memoirs. ${ }^{2}$ From these we learn that the chief work undertaken has been the preparation of a geological map of Russia on the scale of 10 versts $(6.7$ miles) to an inch. Russia has been divided into ten regions : Baltic, Central, Dnieper, Western Frontier, Volga and Don, Caspian, Ural, Crimea and Caucasus, Northern, and Finland. The survey has been started in several regions at once, each region being subdivided into three parts : (I) those which are well explored, and the maps of which already exist and could be employed for geological purposes ; (2) those in which various isolated explorations have been made ; and (3) unexplored parts. The explorations will be prosecuted first of all in the second of these three areas. The system of culours for the map will be adopted which was recommended by the Congress of Bologna. The explanations, as also the chief names, will be printed in French, side by side with the Russian text.

The first volume of the Memoirs contains a work by M. Lahusen, on the Jurassic fauna of the Government of Ryazan, written in Russian, with a summary in German. It is a complete enumeration of the Jurassic fossils of the region, the deposits of which belong-the black clay, with Cardioceras cordatum, to the Lower Oxfordian; the oolitic gray clay, with iron and Cardioceras lamberti, to the Upper Callovian ; the gray and brown clays, with Perisphinctes mosquensis and mutatus, to the Middle; and the brown iron sandstone, with sheets of black clay and characterised by Cosmoceras gowerianum, Cardioceras chamusseti, and Stephanoceras elatine, to the Lower Callovian. The new fossils of the Aucella sandstone will be described by M. Nikitin. Eleven quarto plates illustrating a great number of species, many of which are new, accompany the paper.

The Bulletin (Iavestia) contains, besides the minutes of meetings, a number of preliminary reports of the geologists of the Survey, and the description, by M. Nikitin, of the sheet 58 (Yaroslavl) of the geological map of Russia. These notices are full of valuable information regarding the details of the geological structure of Russia. Among papers of more general interest we may mention Prof. Fr. Schmidt's report upon his explorations on the Baltic Railway, which embodies the results of his prolonged researches in the same region (vol, ii. fasc. 5). It has long been known that Esthonia is built up of Silurian formations, from beneath which rises the Cambrian Ungulite sandstone characterised by Obolus apollinis. After the emergence of the Silurian deposits, the country remained for a vast period a barren land undergoing atmospheric denudation. During this long lapse of time the terrace of the Glint, which runs from Lake Ladoga to Baltisch Port, was formed. During the Glacial period the country was covered with an immense ice-sheet, which moved south-west in its western parts, due south in the middle, and south-east in its eastern parts. The bottom moraine of this ice-sheet spreads over the country, and consists of a mixture of far-transported bulders with debris of the local rocks. It is the equivalent of the British Till and of the Swedish Krossstensgrus. It sometimes gets the local name of Richk. It rises into elongated hills or "drums," which extend also throughout the Government of Novgorod, and must be distinguished from the Åscar. These last, in the opinion of Prof. Schmidt, who indorses the explanation of A. Törnebohm, are shore-walls of those mighty sub-glacial rivers, so well described by Nordenskjöld, which circulate on the surface of the icesheets, and, after having found an exit through the ice, run beneath it.

During the first part of the Post-Glacial period the Gulf of Finland, and probably all the northern part of the Baltic Sea, formed an immense lake which subsequently was connected with the ocean, and received its brackish-water fauna. The level of this lake was about 60 feet higher than the present level of the Baltic. The presence of Baltic shells at grenter heights in the north (the author of this notice found them at 124 feet, on

I Irvestia geologicheskago Komiteta, vols. i, and ii, (fasc. I to 6), 1882 and $1883 .-$ Trudy geologicheskago Komiteta, vol. i. lasc. I; 4 to. (St Petersburg, I883.) 